\title{
JUVENTUDES em foco
}

Caríssimos/as Leitores/as,

Em sua 15a edição, a e-Mosaicos - Revista Multidisciplinar de Ensino, Pesquisa, Extensão e Cultura do Instituto de Aplicação Fernando Rodrigues da Silveira (CAp-UERJ) traz contribuições acadêmicas que circulam pelos vieses acerca dos temas escola, juventude e consumo, constituintes da edição temática, e para além dele.

Com foco principal na educação básica, o tema desta edição tem o propósito, na perspectiva do caráter interdisciplinar da revista, de vincular artigos que dialoguem sobre as juventudes e a diversidade dos seus atos e ações voltados a todo e qualquer tipo de consumo - assim compreendido - no espaço escolar. Os trabalhos submetidos à essa edição são artigos oriundos de pesquisas acadêmicas que vêm contribuir para a difusão do conhecimento acerca do processo dinâmico de formação escolar dos jovens na educação básica e sua ampla relação com o consumo de tudo que os cercam no cotidiano.

A proximidade com o repertório de consumo das juventudes no ambiente da escola nos leva a problematizar um diálogo processual condizente com os estudos sobre o sistema de significações sociais com os quais os alunos estabelecem - seja por meio da sistemática de suas condutas e das relações coletivas e culturais, seja com as possibilidades subjetivas e autorais. Diante disso, essa edição temática visa difundir uma maior proximidade com as narrativas e as identidades culturais difusas entre consumo, juventudes e escola.

Trazemos, ainda, uma entrevista com Eliane Ribeiro, Professora na área de Educação da UNIRIO. Num bate papo informal, Eliane conta-nos sobre sua pesquisa no campo da EJA e das juventudes, sobretudo no que se refere à formação escolar e às trajetórias dos jovens que estão fora da escola e do mundo do trabalho (os "nemnem"), considerando as desigualdades e possibilidades com as quais lidamos no contexto brasileiro.

De certa forma, damos continuidade à última edição uma vez que também trazemos a diversidade na escola e na educação diante as complexidades acerca das juventudes. Assim como na edição 14, ressalva-se que por escola entende-se não somente os espaços educativos formais, mas todos os espaços em que a prática educativa e os processos de escolarização podem se materializar.

Essa edição, na primeira parte, está composta por artigos relacionados ao tema, propriamente dito, da edição temática:

O artigo Juventudes em trânsito: notas etnográficas sobre a relação dos estudantes do ensino médio com o conhecimento escolar, de Luís Paulo Borges, questiona como jovens estudantes do Ensino Médio de uma escola pública da rede estadual do Rio de Janeiro se relacionam com o conhecimento escolar. Assim, 


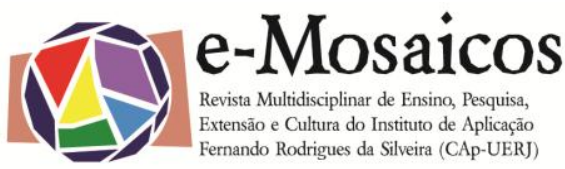

defende a ideia de que o conhecimento escolar possibilita, como dimensão criadora dos modos de subjetivação e diferença, permitir a emergência dos trânsitos juvenis presentes na escola de hoje.

Os autores Pedro Henrique Souza e Jacqueline Girão, no artigo Estranhos no ninho: juventude, consumo e escola, apresenta pesquisa desenvolvida em educação ambiental numa universidade pública carioca e que tem como recorte a relação dos jovens com as práticas do consumo e de que forma ocorrem as mediações de gestores, técnicos e docentes na escola. Os autores refletem sobre os jovens como sujeitos sociais capazes de interpretar e dar sentido ao mundo.

Sou homem! bebi para não 'pagar' de bobão: juventude, consumo e identidade de gênero, de Everson Guthierrez e Jonê Baião traz uma pesquisa que tem como tema juventude, consumo e gênero. Com enfoque no cotidiano de uma escola e na observação da ocupação dos espaços escolares, dialoga sobre as identidades dos modos de ser garota/garoto na juventude.

Em Projeto Santos jovem doutor - desdobramentos para uma aprendizagem significativa em saúde na educação básica, Elisete Natário apresenta resultados da de investigação sobre desdobramentos da prática educativa em ações vinculadas ao conhecimento do corpo humano, que transcendem os muros da escola, isto é, para responsáveis e comunidade do entorno.

Tatiana Luna e Anatália Kutianski, no artigo O consumo de informações sobre saúde por adolescentes do $8^{\circ}$ ano do ensino fundamental, abordam o avanço tecnológico como impulsionador da informação como um bem de consumo e com valor jurídico. Em outras palavras, discute como o acesso à informação se configura como fundamental para a tomada de decisões na chamada sociedade da informação. Para tanto, as autoras apontam como foram realizadas coleta de dados e observações durante as aulas de Ciências no $8^{\circ}$ ano do Ensino Fundamental por meio de um questionário quali-quantitativo que possibilita analisar os meios pelos quais os alunos buscam e utilizam informações tendo como viés a promoção da saúde e qualidade de vida na escola.

O artigo \#Conecte-se, participe e aprenda história: relações entre juventude e conhecimento histórico no espaço escolar em contextos urbanos, Maria Aparecida Cabral apresenta-nos resultados das atividades científicas na área de história - do ensino à historiografia - ao problematizar os usos políticos das diversas mídias comunicativas e demais tecnologias da informação e comunicação nas atividades de formação. Focaliza-se um conjunto de práticas construídas nesse contexto formativo em que a colaboração, a empatia e o protagonismo dos partícipes tornam-se elementos fundamentais para se pensar novas perspectivas para o ensino e a aprendizagem.

O sétimo artigo desta sessão, de autoria de Cristiano Sant'Anna e intitulado \#Diferença: imagens dentrofora da escola, parte de imagens compartilhadas por estudantes do Ensino Médio para abordar a temática da diferença por meio de uma pesquisa-intervenção. Aspectos que permitiam dialogar com a noção de diferença tiveram espaço, permitindo refletir sobre imagens e diferença. 
Essa edição traz, também, artigos de temática livre - e que, de certa forma, mantém o foco nas juventudes.

$\mathrm{O}$ artigo que inaugura essa seção, $O$ moddle como suporte para o ensino de desenho geométrico, de autoria de Luciene Zanardi e Francisco Mattos, aborda o ensino da disciplina Desenho no Colégio Pedro II, considerando as dificuldades de aprendizagem dos estudantes nessa disciplina e possibilidades para os estudantes acompanharem o desenvolvimento dos conteúdos por meio de um ambiente visual de aprendizagem. Este ambiente virtual, além de apostila impressa constituem produto educacional apresentado no Mestrado Profissional de um dos autores.

A produção de documentários ambientais sobre o Parque Nacional da Tijuca para valorização e preservação da Mata Atlântica, dos autores Amanda de Queiroz, Marcelo Rocha, Roberta da Matta, Alexander Ramos, Luisa Queyroi, por sua vez, apresenta trabalho decorrente de processos de divulgação científica sobre espaço relevante do ponto de vista ambiental, apontando o potencial educativo das unidades de conservação (UC).

Derrubando muros e cercas: novas abordagens para o ensino da geografia no século XXI, de Leonardo Marino, destaca a escola como um lugar central ainda que, nas últimas décadas do século $X X$, esteja imersa em contextos de crise que se refletem no seu cotidiano. Discute, para tanto a transição das sociedades disciplinares para as sociedades de controle. Propõe, ainda, investigar a contribuição da educação geográfica no atual contexto. Narrativas autobiográficas sobre práticas reflexivas na formação do professor de língua inglesa do programa PIBID, de Isabel Marson e Clarita de Camargo propõem discutir as práticas de ensino e também do papel do professor reflexivo para maior autonomia na profissão.

Natália Machado e Frederico Cruz, em $A$ importância dos materiais concretos para a construção de conceitos: abordando comprimento, área e volume, mostra-nos a relevância dos conteúdos abordados em sala de aula estabelecerem relação com a vida diária dos alunos e como os saberes produzidos repercutem no processo de aprendizagem quando há interação dos alunos com os conceitos estudados.

Desejamos a todos excelente leitura. E até a próxima edição.

Andrea Fernandes e Christiane Arcuri

Editora da e-Mosaicos - Revista Multidisciplinar de Ensino, Pesquisa, Extensão e Cultura do Instituto de Aplicação Fernando Rodrigues da Silveira (CAp-UERJ) 